Joanna Lubecka, Spór o słowa. Rola semantyki w polsko-niemieckim krajobrazie historycznym, [w:] Krajobraz semantyczny wsi i miast, red. Józef Marecki, Lucyna Rotter, Kraków 2016, s. 263-286 (Symbol - Znak - Rytuał).

DOI: http://dx.doi.org/10.15633/9788374385183.16

dr Joanna Lubecka

Akademia Ignatianum, Kraków

\title{
Spór o słowa. Rola semantyki w polsko-niemieckim krajobrazie historycznym
}

„Człowiek może zostać, dosłownie, zatruty przez

fałszywe pojęcia i fałszywe nauczanie"

Alfred Korzybski ${ }^{1}$

Abstract: This articles aims to demonstrate the role of semantics in the creation and implementation of the historical policies. The first part shows the correlation between semantics and political history. The second and main part of this article analyses three concrete cases in their use of semantical instruments. These cases, it is argued, have influenced the histori-

1 Alfred Korzybski (1879-1950) był wybitnym polskim naukowcem, pracującym i publikującym w Stanach Zjednoczonych, stworzył pojęcie semantyki ogólnej, która zajmowała się wpływem języka na świadomość ludzką oraz możliwością przekształcenia tego wpływu. Błędy obciążające język i negatywnie wpływające na społeczeństwo to np. nieprecyzyjność, skłonność do nadmiernej abstrakcji, niejasność, podatność na manipulacje. Celem semantyki generalnej wg Korzybskiego jest ulepszenie stosunków międzyludzkich przez ulepszenie języka. 
cal narrative, and eventually shifting the historical memory of World War II. These cases are: 'German crimes' a concept used by the Polish forces, 'Polish concentration camps' a concept used by the German forces and finally 'Auschwitz'. The chosen and discussed examples will demonstrate the strong influence of semantics in the mutual relations of both countries.

Key words: political history, semantics, 'German crimes', 'Polish concentration camps'

\section{Semantyka historyczna, a polityka historyczna}

Zadaniem nauk historycznych jest rekonstrukcja przeszłości. Ten oczywisty cel historyk realizuje za pomocą opisu, w którym filtracja wydarzeń i deformacja następują nie intencjonalnie, lecz wynikają z samego faktu użycia danego systemu pojęciowego i języka, który sam w sobie też jest zmienny w czasie ${ }^{2}$. Opis jest tym, co pozostaje nam po faktycznych wydarzeniach. Obiektywna rzeczywistość sprzed wieków daje się poznać kolejnym pokoleniom jedynie dzięki narracji świadków, kronikarzy, historyków. Z założenia będą to opisy subiektywne, nacechowane własnymi przeżyciami i poglądami autorów, modą i stylem epoki, w której pisali. Wybitny niemiecki historyk, znawca i badacz semantyki historycznej Reinhard Koselleck, pisał: istnieje zawsze przemożna różnica między dziejącymi się dziejami a ich językowym umożliwieniem ${ }^{3}$. I dalej: wszystkiego bowiem, co wydarzyło się poza moim własnym doświadczeniem, doświadczam już tylko za pośrednictwem mowy lub pisma 4 . To właśnie „mowa i pismo” konstruują naszą (kolejnych pokoleń) wizję historii, „wytwarzają pamięć”, jak

2 Szerzej o tym zjawisku: R. Koselleck, Semantyka historyczna, wybór i oprac. H. Orłowski, Poznań 2001.

3 R. Koselleck, Dzieje pojęć. Studia z semantyki i pragmatyki języka społeczno-politycznego, Warszawa 2009, s. 12.

4 Tamże, s. 15. 
mówili starożytni Grecy. Mówienie i pisanie nadaje trwałość temu, co nie pozostawia po sobie śladu i jest ulotnes. Jak podkreśla jednak Hannah Arendt w swoim eseju na temat koncepcji historii: jest ona [historia - JL] selekcja z potencjalnie nieograniczonego obszaru przeszłych, przeżytych biernie lub czynnie historii ${ }^{6}$. Paul Ricoeur ujmuje to jeszcze prościej: Skoro nie można przypomnieć sobie wszystkiego, nie można też wszystkiego opowiedzieć. Idea wyczerpującej opowieści jest idea performatywnie niemożliwa․

Historyk skazany jest więc z natury swojej profesji na wybór. Wybory historyka - co opisywać i jak opisywać - mają kilka aspektów, z których wymienimy tu tylko trzy istotne dla naszego tematu: po pierwsze, dystans czasowy do opisywanych wydarzeń. Bycie naocznym świadkiem wydarzeń lub nawet bycie współsprawcą - do XviII w. uznawane było wręcz za gwarancję prawdziwości i rzetelności opowiadanej historii. Zasadniczą zmianę wprowadził w tej kwestii historyzm, za ojca którego uważa się wybitnego niemieckiego historyka Leopolda von Ranke (1795-1886), według którego zasadniczym zadaniem historyka jest opisanie, „powiedzenie tylko tego, co właściwie się stało” („blos sagen, wie es eigentlich gewesen"), a do tego niezbędny jest dystans czasowy (a więc również emocjonalny) do opisywanych wydarzeń ${ }^{8}$ Po drugie, o perspektywie decyduje pozycja społeczna lub polityczna historyka. W tym kontekście na szczególną uwagę zasługuje kategoria „przegrany - wygrany”. Zarówno Tukidydes, piszący Wojnę peloponeską, Tacyt, piszący Dzieje, jak i Machiavelli, piszący Księcia, byli ludźmi (w danym momencie) przegranymi. Przegrany patrzy z innej perspektywy, opisując wydarzenia rozwija odmienne, często nowe wątki, analizuje

5 H. Arendt, Pomiędzy czasem minionym a przyszłym, Warszawa 2011, s. 77.

6 H. Arendt, Koncepcja historii: starożytna i nowożytna, [w:] H. Arendt, Pomiędzy czasem minionym a przyszłym..., s. 78.

7 P. Ricoeur, Pamięć, historia, zapominanie, Kraków 2012, s. 590.

8 L. von Ranke, Geschichten der romanischen und germanischen Völker von 1494 bis 1535, t. 1, Berlin-Lipsk 1824, s. V-VI. 
błędy i przyczyny swojej klęski. Presja na wyjaśnienie przyczyn klęski skłania autorów do głębszej analizy wydarzeń. Po trzecie, o wyborach historyka decyduje to, czy należy do politycznej, religijnej, społecznej lub ekonomicznej jednostki działania, o której opowiada i czy się z nią identyfikuje poprzez bezpośrednie działanie w jej ramach lub afirmatywne utożsamianie się z nią, czy też patrzy na nią z zewnątrz. Z powyższego wynika więc, iż mimo najlepszych intencji historyka, jego przekaz będzie z obiektywnych powodów odbiegał od ideału Rankego.

Koselleck, zwracając uwagę na konstytutywną (czasem wręcz kreatywną) rolę narracji historycznej, wyróżnia trzy etapy „tworzenia” historii. Pierwszy z nich to tak zwany akt pierwszego spisania, drugi - przepisywanie, trzeci - przerabianie (Umschreiben)9. Ostatni etap, którego polskie niedoskonałe tłumaczenie sugeruje intencjonalną zmianę treści, a więc i manipulację historią, niekoniecznie musi mieć znaczenie pejoratywne. „Przerabianie” może być skutkiem odkrycia nowych źródeł lub ich ponownej historyczno-filologicznej krytyki. Takie „przerabianie” racjonalnie uznajemy za zadanie historyka.

W narracji historycznej słowo (pojęcie) odgrywa kluczową rolę, to ono tworzy obraz przeszłości (często emocjonalny). W historii pojęć wiele jest słów-kluczy, które opisują szerszą rzeczywistość (np. „zimna wojna”, „żelazna kurtyna”, „Holocaust”). Niektóre niosą duży ładunek emocjonalny, choć w różnych krajach, kręgach kulturowych mogą znaczyć coś innego („wyzwolenie” w 1945 r. będzie miało inne znaczenie dla Niemca, inne dla Polaka, a jeszcze inne dla Francuza). Ta dyferencja pojęć, ich znaczeń i równocześnie świadomość, że słowa mogą zmieniać percepcję przeszłości, tworzy bardzo niebezpieczny margines instrumentalizacji historii. Kiedy pojęcia stana się niemożliwe do zastapienia i niewymienialne, staja się pojęciami podstawowymi, pojęciami, bez których nie może obyć się żadna wspólnota polityczna i językowa. Zarazem stają się sporne, ponieważ różni użytkownicy języka

9 R. Koselleck, Dzieje pojęć..., s. 50-51. 
chca narzucić innym monopol interpretacji ${ }^{10}$. Kto jest więc tym „użytkownikiem języka”, chcącym narzucić własną interpretację dziejów? Nie jest celem niniejszego artykułu teoretyczne rozważanie na temat pojęcia „polityki historycznej”, wokół którego narosło wiele kontrowersji i którego precyzyjna definicja nadal pozostaje sporna. Chodzi o to, aby ukazać w jaki sposób semantyka staje się narzędziem polityki historycznej.

Dla potrzeb niniejszego artykułu przyjęto definicję, w której najistotniejszy jest element wykorzystania historii lub jej odpowiedniej interpretacji w celach politycznych. Anna Wolff-Powęska nazwała to po prostu „historią w służbie polityki”" wobec polityki intuicyjnie wywołuje negatywne skojarzenia z manipulacją, instrumentalizacją. Jeśli jednak głębiej zastanowić się nad tym problemem można zauważyć wiele racjonalnych przesłanek przemawiających za swego rodzaju ukierunkowaniem narracji historycznej, szczególnie z perspektywy państwa. Jeśli, jak już wykazano, narracja historyczna z natury rzeczy jest przekazem selektywnym i w znacznej mierze zależy od narratora, dlaczego nie uznać ingerencji na rzecz dobrze rozumianej racji stanu za rzecz dopuszczalną? Oczywiście pozostaje zawsze pytanie, kto ma dokonywać selekcji, w jakich granicach jest ona dopuszczalna i jaki jest cel tej ingerencji.

Świadome sformułowanie i używanie pojęcia polityki historycznej zawdzięczamy właśnie Niemcom (Geschichtspolitik). Historycy niemieccy, między innymi Leopold von Ranke czy jego uczeń Heinrich von Sybel, pierwsi kładli silny nacisk na profesjonalizację badań historycznych. Tacy zaś jak Heinrich von Stein ${ }^{12}$, Wilhelm von Humboldt

10 Tamże, s. 104.

11 A. Wolff-Powęska, Geschichtspolitik. Geschichte im Dienst der Politik, November 2006, http://www.transodra-online.net/de/node/1255 [29 VI 2015].

12 Heinrich von Stein był pomysłodawcą i twórcą zbioru dokumentów dotyczących historii Niemiec - Monumenta Germaniae Historica jest wydawana z jego inicjatywy od 1819 r. Dla porównania Monumenta Poloniae Historica jest wydawana od $1864 \mathrm{r}$. 
świadomie, ale i rzetelnie traktowali historię jako narzędzie polityki. Określenie „rzetelnie” jest tu kluczowe. Polityka historyczna jest faktem i prowadzenie jej nie jest samo w sobie zjawiskiem negatywnym. Ważne, jak podkreślali jej niemieccy twórcy, aby nie służyła manipulacji (Geschichtsfälschung) bądź mitologizacji (Mythologisierung). Rzetelna polityka historyczna może służyć do wzbudzania i budowania odpowiedzialności społeczeństw za czyny przodków, powinna również przyczyniać się do budowy istotnej pozycji państwa na arenie międzynarodowej. Może również wzmacniać wieloaspektowość patrzenia na dzieje. W żadnym wypadku nie chodzi tu jednak o stosowanie zasad poprawności politycznej i szukanie za wszelką cenę wspólnych ocen, lecz o próbę zrozumienia „obcej” interpretacji tych samych wydarzeń ${ }^{13}$.

Niemieccy historycy w Xıx wieku jako pierwsi docenili rolę edukacji historycznej, jako elementu budującego wspólną tożsamość narodu, właśnie dlatego wspierali edukację patriotyczną w szkołach (szczególnie w Prusach). Jak pisał wybitny znawca historii Prus Stanisław Salmonowicz: Monarchia popierała oświatę z przesłanek ideologicznych, jako metode ideologicznego nacisku na poddanego, a przede wszystkim jako element rozwoju gospodarczego ${ }^{14}$. Być może taki model wewnętrznej polityki historycznej w Prusach nie budzi naszego entuzjazmu, ale w dobry sposób ukazuje instrumentalizację historii dla potrzeb polityki. Nieco upraszczając, można stwierdzić, iż skuteczność tego modelu edukacji została dowiedziona na polach bitew, co dobitnie spuentował ówczesny czołowy francuski polityk Leon Gambetta, po przegranej z Prusami wojnie 1870 roku: Ostatniq wojnę wygrat pruski nauczy-

13 Piszą o tym m.in. J. Rüsen, Westliches Geschichtsdenken: Eine interkulturelle Debatte, Vandenhoeck und Ruprecht, Göttingen 1999; Zerbrechende Zeit. Über der Sinn der Geschichte, Böhlau, Köln 2001; F. Jaegger, J. Rüsen, Geschichte des Historismus. Eine Einführung, München 1992; Z perspektywy brytyjskiej niezwykle ciekawie pisze o tym A. Giddens, Nowoczesność i tożsamość, Warszawa 2001.

14 S. Salmonowicz, Prusy - dzieje państwa i społeczeństwa, Warszawa 1998, S. 221. 
ciel $^{15}$. Historya - jak pisał Fryderyk Nietzsche - stuży przede wszystkiem działaczowi i mocarzowi ${ }^{16}$, a więc instrumentalnie wykorzystują ją przede wszystkim władze państw, niezależnie od ustroju, choć oczywiście w różnej skali. Riceour nazywa nietzscheańskich mocarzy „wyższymi mocami”, które przejmują kompozycję fabularną narracji historycznej i narzucaja kanoniczna narracje poprzez zastraszenie lub uwiedzenie, strach lub pochlebstwo ${ }^{17}$. W historii Niemiec najdobitniejszym przykładem narzucenia narracji przez władze okazał się okres narodowego - socjalizmu, w którym stworzono cały system semantyczny, odpowiadający nowej władzy ${ }^{18}$.

Tymczasem polityka historyczna demokratycznego państwa nie powinna ignorować pojęcia prawdy historycznej, musi pozostawać w ścisłej $z$ nią relacji. Nie można fałszować historii albo usuwać z niej rzeczy niepięknych, nieładnych ${ }^{19}$.

\section{Przypadek: Niemcy}

Jeśli zgodzimy się, że celem zewnętrznej (zagranicznej) polityki historycznej państwa jest dbanie o jego jak najlepszy wizerunek na arenie międzynarodowej, to zapewne zgodzimy się z tym, że przed rządem Republiki Federalnej Niemiec (powstałej w 1949 r.) stało niełatwe zadanie. Sprzyjająca okazała się sytuacja międzynarodowa - zimna wojna pchnęła RFN w objęcia Zachodu, drażliwe pytania pozostały

15 M. N. Rothbard, Edukacja wolna i przymusowa, Warszawa 2014, s. 47.

16 F. Nietzsche, Niewczesne rozważania, tłum. L. Staff, Warszawa-Kraków 1912, s. 111.

17 P. Ricoeur, Pamięć..., s. 590-591.

18 Najsłynniejsze dzieło dotyczące manipulacji semantycznych w III Rzeszy napisał wybitny niemiecki filolog Victor Klemperer, LTI (Lingua Tertio Imperia). Notizbuch eines Philologen, Berlin, 1947.

19 Wspomnienie Tomasza Merty na portalu „Krytyki Politycznej” z dnia 15.04.2010, http://www.krytykapolityczna.pl/Opinie/GawinTomaszMerta-wspomnienie/menuid-183.html [27 VI 2015]. 
bez odpowiedzi, co gorsza, w społeczeństwie zachodnioniemieckim zapanowała obojętność wobec III Rzeszy i jak nazwali to nieliczni „uspokojenie niemieckich sumień”

$\mathrm{Ci}$, którzy zauważali tę tendencję, z oburzeniem i wstydem pisali o „drugiej winie Niemiec”, czyli tłumieniu i negowaniu tej pierwszej, lub o „zimnej amnezji”, czy wręcz sarkastycznie o „największym dziele resocjalizacji” dla sprawców zbrodni wojennych ${ }^{21}$. Dla nowych władz niemieckich, na czele których stał kanclerz Konrad Adenauer najważniejsza była wewnętrzna integracja społeczeństwa niemieckiego oraz odbudowa zniszczonej wojną gospodarki. Sprawę rozliczenia zbrodni niemieckich uznawał za załatwioną w procesach norymberskich, a wracanie do niej uznawał za działanie szkodliwe i antypaństwowe. Jego słowa wypowiedziane w $1951 \mathrm{r}$. dobrze odzwierciedlały przekonania społeczeństwa zachodnioniemieckiego: Pora przestać węszyć za nazistami. Jeśli raz zaczniemy, nie wiadomo dokąd nas to zaprowadzi...22. Rząd RFN nie uznawał prawa norymberskiego, a więc zbrodniarze sądzeni byli jak zwykli kryminaliści, za morderstwo i w najgorszym razie groziła im kara dożywotniego więzienia. Niemiecki kryminolog, Dieter Schenk nazwał politykę rządu, administracji i wymiaru sprawiedliwości w latach 50-tych i 6o-tych strukturalnym nieściganiem

20 W latach 1945-1949 ukazało się kilka dzieł znaczących autorów na temat moralnego rozliczenia się Niemców z III Rzeszą, m.in.: K. Jaspers, Die Schuldfrage, Heidelberg 1946; A. Weber, Haben wir Deutsche nach 1945 versagt?, München 1949; F. Meinecke, Die Deutsche Katastrophe. Betrachtungen und Erinnerungen, Wiesbaden 1946; G. Ritter, Europa und die deutsche Frage, Betrachtungen über die geschichtliche Eigenart des deutschen Staatsdenkens, München 1948 i inne. Dzieła te nie spowodowały jednak ogólnonarodowej debaty o winie Niemców.

21 R. Giordano, Die zweite Schuld oder Von Last Deutscher zu sein, Hamburg 1987; J. Friedrich, Die kalte Amnestie. Ns-Täter in der Bundesrepublik, Frankfurt a.M. 1985.

22 N. Frei, Vergangenheitspolitik: Die Anfänge der Bundesrepublik und die NS-Vergangenheit, München 1996, s. 60. 
morderców ${ }^{23}$. Schenk podaje, iż w 1950 roku 66-75\% sędziów i prokuratorów było dawnymi członkami NSDAP ${ }^{24}$. Jeśli już ktoś stawał przed sądem, obrońcy i sędziowie stosowali kilka prostych procedur. Uznawano, że oskarżeni działali w systemie totalitarnym, a więc nie mogą odpowiadać jako sprawcy, gdyż działali „w stanie wyższej konieczności wywołanej rozkazem". Poza tym, ich czyny to nie ludobójstwo, lecz tzw. czyny wojenne, a więc dopuszczalne przez prawo międzynarodowe. Na korzyść oskarżonych miał przemawiać również charakterystyczny dla Niemców szacunek dla władzy i państwa. Procesom towarzyszyło społeczne przekonanie, że niesprawiedliwością jest karanie wykonawców, podczas gdy rozkazodawcy (Hitler, Himmler) uniknęli odpowiedzialności. Nie wnikając w szczegóły debat historycznych i nielicznych procesów, które miały miejsce w RFN w latach powojennych, warto podkreślić wyraźną zmianę jaka zaszła w narracji historycznej dotyczącej II wojny światowej po zjednoczeniu Niemiec w 1990 roku $^{25}$. Rację bytu straciły grupy „rewizjonistów” pokroju Herbert Czai, czy Herberta Hupki ${ }^{26}$, kwestionujące granicę polsko-niemiecką, reprezentujące jednak zdecydowanie marginalne w społeczeństwie niemieckim opinie. Dziś narracja niemiecka jest elementem nowoczesnego soft power $^{27}$ i posługuje się instrumentami marketingu politycznego. Takie

23 D. Schenk, Noc morderców. Kaźń polskich profesorów we Lwowie $i$ holokaust w Galicji Wschodniej, Kraków 2011, s. 305.

24 Tamże, s. 311.

25 Debaty, również o większym społecznym zasięgu odbywały się w RFN przy okazji różnych wydarzeń m.in. procesów (tzw. proces Tilsit, proces Eichmanna, proces frankfurcki). Ale również wywoływali je historycy, intelektualiści (spór o tak zwane tezy Fischera, Historikerstreit, wystawa poświęcona zbrodniom Wehrmachtu oraz debata Walser-Bubis).

26 Herbert Czaja (1914-1997), Herbert Hupka (1915-2006) - niemieccy politycy chadeccy, działacze niemieckiego Związku Wypędzonych, kwestionujący granicę polsko-niemiecką na Odrze i Nysie Łużyckiej, znani z ostrych wypowiedzi antypolskich, w latach 9o-tych obaj zaangażowali się w pojednanie polsko-niemieckie.

27 Soft power - pojęcie sformułowane prze Josepha Nye (ur. 1937), doktora nauk politycznych Uniwersytetu Harwarda. Definiuje się jako „zdolności 
zabiegi w kontekście wyżej opisanej roli słowa, wydają się dużo bardziej niebezpieczne w skutkach, gdyż mogą powoli i niezauważalnie zmieniać obraz przeszłości.

Winston Churchill, mówiąc: Historia będzie dla mnie łaskawa, bo sam mam ja zamiar napisać, ujął sens „walki na słowa”. Odpowiednie zestawianie słów, pojęć tworzy nową hierarchię byłych zdarzeń, zmienia ich kontekst, pozwala inaczej kategoryzować (np. odchodzić od aspektów narodowych, a przechodzić do bardziej uniwersalnych, np. praw człowieka). Poniżej przedstawiono i omówiono trzy przykłady „sporu semantycznego", które mają zasadnicze znaczenie w polsko-niemieckim krajobrazie historycznym.

\section{Exemplum 1: Niemieckie zbrodnie}

Terminologia związana ze zbrodniami wojennymi okupanta niemieckiego na ziemiach polskich nadal nie jest uporządkowana. Zarówno w literaturze fachowej, jak i w języku codziennym funkcjonuje obok siebie wiele określeń: zbrodnie niemieckie, zbrodnie nazistowskie, zbrodnie hitlerowskie. Precyzja terminologiczna wydaje się w tym przypadku niezbędna. Spójne, logicznie wywiedzione zalecenia używania konkretnych terminów do określenia zbrodni okupanta niemieckiego zapobiegają dezorientacji, a nawet relatywizmowi historycznemu, służą również edukacji historycznej i budowaniu odpowiedzialnego patriotyzmu. Konsekwentne używanie określeń umożliwia również władzom państwowym i lokalnym zsynchronizowane i jednoznaczne reakcje na przypadkowe i celowe przekłamania, pojawiające się w międzynarodowej opinii publicznej. W Niemczech w zasadzie nie

narodu lub kraju do pozyskiwania sojuszników i zdobywania wpływów dzięki atrakcyjności własnej kultury, polityki, ideałów politycznych", J. Nye, Soft Power. Jak osiagną́ sukces w polityce światowej-perswazyjne środki oddziaływania politycznego (kultura, propaganda, dyplomacja), Warszawa 2007. 
używano pojęcia zbrodnie niemieckie. Szczególnie politycy starali się nie łączyć zbrodni II wojny z narodem niemieckim, a zasadę używania pojęcia „nazistowski” zamiast „niemiecki” wprowadził już kanclerz Konrad Adenauer. Używano więc w języku publicznym sformułowań, takich jak „zbrodnie nazistowskie”, „wojna Hitlera”, „zbrodnie popełnione w imieniu narodu niemieckiego". Obecnie najczęściej używa się terminu Nazi - Verbrechen (zbrodnie nazistowskie).

Terminologia ta posłużyła z czasem do rozmycia świadomości opinii publicznej, kim byli naziści. Świetnym przykładem argumentacji niemieckiej jest felieton niemieckiego profesora, skądinąd niezwykle przyjaźnie nastawionego do Polski, Klausa Bachmanna ${ }^{28}$. W reakcji na pismo Instytutu Pamięci Narodowej do władz samorządowych w sprawie używania w miejscach upamiętnienia ofiar II wojny określenia „niemieckie” (zbrodnie niemieckie, niemieckie obozy koncentracyjne i zagłady, niemiecka okupacja itd.) Bachmann zwraca uwage, że nazwa „zbrodnie niemieckie” zmienia kategorie ideologiczne na narodowe i prowadzi do utożsamiania sprawców z jednym tylko narodem. Pisze również, że takie nazewnictwo wypacza historię, gdyż „nie wszyscy Niemcy byli nazistami, a bardzo dużo fanatycznych zwolenników nazizmu nie było Niemcami”. Na poparcie własnych argumentów podaje ewentualne skutki takiej zmiany: „zbrodnie jednych Włochów na drugich przestałyby być zbrodniami faszystowskimi, a stałyby się zbrodniami włoskimi. Zbrodnie sowieckie stałyby się zbrodniami rosyjskimi”29. Klaus Bachmann nie myli się co do faktów, ale nie bierze pod uwagę jednej zasadniczej kwestii - zarówno nazista austriacki, jak i urzędnik niemiecki pracujący w GG lub w obozie koncentracyjnym, niebędący nawet narodowym socjalistą, byli przedstawicielami Niemieckiej Rzeszy - Deutsches Reich ${ }^{30}$, reprezentowali jego interesy,

28 K. Bachmann, Historia w krzywym zwierciadle, „Gazeta Wrocław”, 14.12. 2008.

29 Tamże.

30 Popularna nazwa Trzecia Rzesza (Dritten Reich) była nieoficjalną nazwą państwa niemieckiego w latach 1933-45. 
a pracą dla niego legitymizowali, choć często nie bezpośrednio, działalność swego kraju, w tym jego zbrodnie ${ }^{31}$. Obozy koncentracyjne budowała nie partia, lecz państwo niemieckie, do niego też należało administrowanie systemem obozów, to również państwo ciągnęło zyski z niewolniczej pracy więźniów i z zagrabionego im majątku. Stąd nazywanie tych zbrodni niemieckimi nie utożsamia ich z narodem, lecz z państwem niemieckim.

Za bezwzględnym używaniem określenia „niemieckie” zbrodnie, obozy i in. przemawia fakt, że sformułowanie „nazistowskie/naziści” z czasem traci w opinii publicznej swoją konotację z narodem niemieckim, o czym świadczy wiele badań przeprowadzonych w Stanach Zjednoczonych, Australii, Kanadzie, ale niestety również w Europie ${ }^{32}$. Naziści stają się mitycznym narodem, niewiadomego pochodzenia. Lub z czasem w narracji dotyczącej II wojny, nazistami stają się Litwini, Ukraińcy lub Polacy (o czym poniżej).

31 Można wierzyć w to, że na terytorium Niemiec wielu Niemców nie wiedziało o zbrodniach dokonywanych na terytoriach okupowanych. Nie do obrony jest jednak teza, że można było pozostać nieświadomym zbrodni niemieckich, przebywając na terytoriach okupowanych, szczególnie na wschodzie.

32 Badania, wywiady robione z uczniami szkół amerykańskich dobitnie ukazują, iż nie tylko obozy koncentracyjne kojarzone są z Polską, wykazują również powszechność opinii, że naziści to Polacy, zob. m.in. J. Ławrynowicz, M. Ławrynowicz, „Polish Concentration Camps”. Zarys chronicznego problemu, „Przegląd Polski”, 28.01.2005; K. Zuchowicz, P. Zychowicz, Wygrywamy walkę o prawdę, „Rzeczpospolita”, 22. 04. 2006; Prof. Witold Kieżun dla WP.PL: większość moich studentów uważa Polaków za nazistów, wywiad z prof. Kieżunem dla Wirtualnej Polski, 15.07.2014, http://historia.wp.pl/title,Prof-WitoldKiezun-dla-wPPL-wiekszosc-moich-studentow-uwaza-Polakow-za-nazistow, wid,16753214, wiadomosc.html?ticaid=1152c2 [28 vi 2015]; Kieżun relacjonuje, że na pytanie jakiej narodowości byli naziści „na 102 studentów 62 napisało polskiej. Zapytałem: „dlaczego?” Odpowiedzieli: „Dlatego, że sa polskie obozy koncentracyjne. A wiadomo, że obozy koncentracyjne byly organizowane przez nazistów, żeby mordować Żydów. Wobec tego naziści to są Polacy”. I w tej chwili cały świat tak uważa" (28 vi 2015). 
Na koniec warto ukazać, w jaki sposób można prowadzić „walkę semantyczną" $\mathrm{z}$ wykorzystaniem nowoczesnych technologii. Po wpisaniu w przeglądarce internetowej (google.de) określenia „deutsche Verbrechen in Polen" (niemieckie zbrodnie w Polsce) jedynie na dwóch pierwszych miejscach pojawiają się strony dotyczące zbrodni Wehrmachtu w Polsce oraz niemieckiej okupacji w Polsce, pozostałe dotyczą zbrodni polskich popełnionych na Niemcach i Volksdeutschach (jedna z nich obejmuje zakres czasowy od 1681 do 1939 r.).

\section{Exemplum 2: Polskie obozy}

O „polskich obozach” zrobiło się szczególnie głośno, gdy w 2012 roku prezydent Barak Obama użył tego właśnie sformułowania w czasie uroczystości pośmiertnego nadania Prezydenckiego Medalu Wolności Janowi Karskiemu. Bolesny paradoks tej sytuacji polegał na tym, że Jan Karski na własne oczy widział życie (a może raczej śmierć) w getcie warszawskim i obóz niemiecki w Izbicy, który Obama nazwał „polskim obozem”. Jako kurier Polskiego Państwa Podziemnego informował świat (m.in. prezydenta Roosevelta) o zagładzie Żydów. Dodatkowy paradoks polegał na tym, że Krzyż odbierał były minister spraw zagranicznych Polski Adam Daniel Rotfeld, który w 2005 r. wraz z redakcją „Rzeczpospolitej” rozpoczął akcję przeciwko używaniu w zagranicznych mediach sformułowania: „polskie obozy” ${ }^{33}$. Historia używania nazwy

33 Adam Daniel Rotfeld, wybitny polski prawnik pochodzenia żydowskiego. W czasie wojny, w 1943 r. Niemcy zabili jego rodziców, a on sam znalazł schronienie w grekokatolickim klasztorze w Uniowie; akcja Msz trwa nieprzerwanie od 2005 roku, jej efekty można obserwować na stronie: www.msz.gov. pl/pl/polityka_zagraniczna/przeciw_polskim_obozom; podobną działalność prowadzi również Polish Media Issues Group, działająca od 2005 r. w Wielkiej Brytanii i stawiająca sobie za cel monitorowanie anglojęzycznych stron internetowych i prasy oraz interweniowanie w przypadku pojawiania się błędnych sformułowań typu „Polish concentration camp” oraz pokrewnych, jak również nieprawdziwych informacji zakłamujących historię Polski. 
„polski obóz” na niemieckie obozy koncentracyjne i zagłady w okupowanej Polsce ma swoją długą historię i łączy się z nazewnictwem wcześniej omówionym, a więc unikaniem nazwy „niemiecki obóz”. Istnieje też domniemanie, niestety ciągle nie potwierdzone naukowo, pojawiające się jedynie w tekstach popularno-naukowych, dotyczące historii terminu "polskie obozy koncentracyjne" ${ }^{34}$. Termin ten miałby być stworzony przez niemiecką tajną komórkę BND (Bundesnachrichtendienst - Federalny Urząd Informacji, czyli Zachodnioniemiecki wywiad), zwaną Agencją 114 (Dienstelle 114), której zadaniem była m.in. destygmatyzacja Niemców. W komórce tej na czele, której stał były sierżant nazistowskiej tajnej policji wojskowej (Geheime Feldpolizei) służyło wielu byłych nazistów. To właśnie oni mieli wymyślić „semantyczne kłamstwo", aby przekonać opinię światową do Republiki Federalnej Niemiec, odcinając ją niejako od aparatu terroru w trakcie II wojny. Część archiwaliów BND jest już dostępna dla badaczy niemieckich, nadal jednak nie mamy potwierdzenia tej teorii spiskowej. Jeśli okazałaby się prawdą, byłby to bardzo ciekawy przykład skutecznej manipulacji semantycznej.

Skoro prasa na świecie, również ta niemiecka, używa określenia "polskie obozy zagłady" (polish Death camps, polnische Vernichtungslager), Polska nie może sobie pozwolić na używanie określeń nazistowskie obozy, które rozmywa odpowiedzialność za zbrodnie. Upieranie się, że chodzi jedynie o konotacje geograficzne (dodajmy, iż w czasie istnienia obozów Polska nie istniała, były to ziemie wcielone do Rzeszy lub znajdujące się na terytoriach przez nią okupowanych) jest trwaniem w błędzie, gdyż znajomość historii Europy w czasie II wojny światowej nie jest już taka oczywista, a z czasem będzie coraz słabsza. Pozostaje też pytanie, dlaczego obozy w Polsce nazywane są polskimi, zgodnie $\mathrm{z}$ „logiką geograficzną”, a obozy leżące na terytorium Niemiec, których było ponad 20, zwane są „nazistowskimi”, a nie „niemieckimi”? Czym wytłumaczyć fakt, że w ten sposób piszą europejskie, renomowane

34 L. Pietrzak, Wielka kariera kłamstwa, „Uważam rze”, 07.04.2013. 
gazety. Z raportu polskiego Msz wynika, że w samym tylko 2009 r. aż 103 razy użyto w zagranicznych mediach określenia "polskie obozy koncentracyjne”. Najczęściej termin ten pojawiał się w prasie niemieckiej (aż 20 razy) ${ }^{35}$. Z przykrością trzeba stwierdzić, że gazety, które w ten sposób pisały, nie należą do lokalnych i niszowych. W większości przypadków są to wielkonakładowe i opiniotwórcze dzienniki lub tygodniki, między innymi „Der Spiegel”, „Bild”, „Der Tagesspiegel”, „Die Welt”, „Die Zeit”, jak również dwie agencje prasowe: niemiecki oddział Reuters oraz DPA (Deutsche Presse Agentur) ${ }^{36}$. Po licznych interwencjach polskiego MSz oraz redakcji „Rzeczpospolitej” większość dziennikarzy niemieckich przepraszała i robiła sprostowania. Zdarzały się jednak i takie tłumaczenia, że w krótkiej, pojawiającej się na ekranie wiadomości (dotyczyło to tekstu telegazety) po prostu nie zmieściłoby się określenie „obozy koncentracyjne wybudowane w Polsce okupowanej przez Niemców” ${ }^{37}$. Trzeba też podkreślić, że do czytelnika, który przeczyta artykuł, w którym pojawia się sformułowanie „polski obóz”, najczęściej nie trafi już sprostowanie zamieszczone kilka numerów później, zamieszczone najczęściej na dalszych stronach gazety. W styczniu 2015 roku, w 70-tą rocznicę wyzwolenia KL Auschwitz, przy okazji komentowania uroczystości odbywających się na terenie byłego obozu, pojawiły się również sformułowania „polskie obozy”. Nie uniknęła ich ani amerykańska CNN, ani niemieckie gazety (m.in. Rheinische Post, Mannheimer Morgen, Rhein Neckar Zeitung $)^{38}$. Oczywiście we wszystkich przypadkach interweniowały polskie służby dyplomatyczne.

35 K. Klinger, MSZ nie radzi sobie z kłamstwami, „Dziennik Gazeta Prawna”, 10.12.2009.

36 Bieżąca lista takich nadużyć znajduje się na stronie Msz, https://www. msz.gov.pl/pl/polityka_zagraniczna/przeciw_polskim_obozom/ (28 vi 2015).

37 K. Zuchowicz, P. Zychowicz, Trzeba ścigać autorów tekstów o „polskich obozach śmierci”, „Rzeczpospolita”, 25.01.2005.

38 M. Pieńkowski, „Polskie obozy” wciąż w zachodnich mediach. Walka trwa, „Rzeczpospolita”, 27.01.2015. 


\section{Exemplum 3: Auschwitz}

Słowo Auschwitz, które jednocześnie jest symbolem zawierającym bardzo silny ładunek emocjonalny, wywołuje dyskusję nie tylko na linii polsko-niemieckiej, ale również pod koniec lat dziewięćdziesiątych wywołał ciekawą debatę w Niemczech. Jej pierwotnym powodem było mimo wszystko pewne nieporozumienie, czy też niezrozumienie, które miało swoje źródła w semantyce. W 1998 r. pisarz Martin Walser otrzymał najbardziej prestiżową w Niemczech nagrodę literacką - Pokojową Nagrodę Niemieckich Księgarzy ${ }^{39}$. Z tej okazji wygłosił przemówienie we frankfurckim kościele św. Pawła, zatytułowane Sonntagsrede, co można przetłumaczyć jako „niedzielna pogadanka”40. Główną osią swojej mowy Walser uczynił niemiecką pamięć zbiorową dotyczącą zbrodni II wojny światowej i przede wszystkim Holocaustu. Podkreślał, że proces upamiętnienia tej historii polega jedynie na przypominaniu Niemcom tych zbrodni, co znacznie utrudnia pozytywny, afirmatywny stosunek narodu do własnej tożsamości. Z drugiej strony zauważa, że często nie pamięć, nie chęć uchronienia przed zapomnieniem, lecz instrumentalizacja naszej hańby do aktualnych potrzeb, stanowi tu główny motyw $w^{41}$. W swojej pogadance Walser nie występował przeciwko kultywowaniu pamięci o Holocauście, lecz przeciwko jej instrumenta-

39 Martin Walser (ur. 1927 r.) jest wybitnym niemieckim intelektualistą i pisarzem, autorytetem zarówno dla liberalnej lewicy, jak i konserwatywnego centrum; zarówno jego pisarstwo, jak i działalność świadczyła o chęci rozliczenia się z niemiecką przeszłością. Z czasem zaczęto mu jednak przypisywać radykalizację poglądów w kierunku bardziej nacjonalistycznych, a nawet antysemickich.

40 W zasadzie pełny tytuł brzmiał: Erfahrungen beim Verfassen einer Sonntagsrede (doświadczenia przy pisaniu niedzielnej pogadanki/mowy); pojęcie Sonntagrede ma w języku niemieckim specyficzne znaczenie. Tym mianem określa się często trywialne, nieistotne z założenia przemówienie. Oczywiście w wydaniu Walsera była to nazwa prowokacyjna; pełny tekst mowy Walsera [w:] Die Walser-Bubis-Debatte. Eine Dokumentation, red. F. Schirrmacher, Frankfurt am Main 1999, s. 7-17.

41 Die Walser-Bubis..., s. 12. 
lizacji i rytualizacji (szczególnie miał tu na myśli zbiorowe, państwowe rytuały). Dalej mówił: Auschwitz nie nadaje się do tego, żeby stać się rutynowym straszakiem, zawsze przydatnym środkiem otrzeźwiającym, moralna maczuga czy jedynie rodzajem obowiązkowego ćwiczenia. Coś co staje się rytuałem, nabiera jakości pośpiesznie szeptanej modlitwy ${ }^{42}$. Tym samym ostrzegał przed nadużywaniem Auschwitz jako figury retorycznej, narzędzia politycznego i medialnego. Zrobił to we właściwym dla siebie stylu, używając wielu metafor i niedomówień (z pewnością z zamiarem sprowokowania poważnej, intelektualnej dyskusji) ${ }^{43}$. Ignatz Bubis, przewodniczący Rady Żydów w Niemczech, odebrał to wystąpienie bardzo dosłownie (tak jak większość opinii publicznej), choć w jednej sprawie z pewnością miał rację - członek duchowej, intelektualnej elity niemieckiej Martin Walser powinien zdawać sobie sprawę, że jego wyrafinowane przemówienie da argumenty skrajnej prawicy ${ }^{44}$. Tak właśnie się stało, niezależnie od zamiarów i intencji Walsera. Bubis zareagował ostro, w trakcie swojego przemówienia w berlińskiej synagodze z okazji rocznicy „nocy kryształowej” nazwał Walsera „duchowym podżegaczem” (geistiger Brandstifter), zarzucając mu chęć odcięcia "grubą kreską" (Schlußstrich) historii Holocaustu i propagowania „kultury odwracania oczu” 45 . Bubis zwrócił również uwagę na słownictwo używane w Sonntagsrede, otóż Walser mówił

42 Tamże, s. 13.

43 Szczegółową analizę językowo-filozoficzną mowy Walsera przedstawił L. Jansen, Alles Schlußstich - oder was? Eine philosophische Auseinandersetzungen mit Martin Walsers Friedenspreisrede, "Theologie und Philosophie” nr 80:2005, s. 412-422; znany niemiecki socjolog Jan Philipp Reemtsma, nazwał przemówienie Walsera „retoryką aluzji”, szerzej patrz: P. Buras, Pamięć jako racja stanu. Niemiecka debata o stosunku do Holocaustu, „Więź” nr 4:1994, s. $142-147$.

44 Ignatz Bubis (1927-1999) był od 1992 r. do swojej śmierci przewodniczącym Centralnej Rady Żydów w Niemczech. Cudem przeżył Holocaust. Stracił całą rodzinę, mimo to po wojnie nie wyjechał z Europy, lecz zamieszkał w Niemczech.

45 Pełny tekst mowy I. Bubisa [w:] Die Walser-Bubis...,, s. 106-113. 
w niej o Holocauście jako o „nieprzemijającej hańbie” (unvergängliche Schande). Słowa "hańba” użył w swoim przemówieniu w odniesieniu do Holocaustu cztery razy, ale jak podkreśla Bubis, ani raz nie użył słowa „zbrodnia”. Ostra dyskusja podzieliła niemieckich intelektualistów, dziennikarzy, opinię publiczną. O ile wcześniejsze debaty skoncentrowane były tylko na przeszłości, o tyle debata Walser-Bubis dotyczyła przede wszystkim słów i pojęć, jakimi opisuje się przeszłość, kształtu pamięci o wydarzeniach, których sama ocena moralna nie budziła w Niemczech kontrowersji.

Innym przykładem semantycznego sporu, tym razem polsko-niemieckiego są okoliczności zmiany nazwy obozu koncentracyjnego w Oświęcimiu-Brzezince z dotychczasowej „Obóz Koncentracyjny Auschwitz” na nową „Były Nazistowski Niemiecki Obóz Koncentracyjny Auschwitz-Birkenau” (2006 r.) ${ }^{46}$. Oba przypadki spotkały się z krytyką niektórych niemieckich gazet. Warto przyjrzeć się argumentacji dziennikarzy niemieckich, gdyż właśnie ta logika staje się coraz bardziej powszechna w Niemczech. Otóż najbardziej oburzony Arno Widmann („Berliner Zeitung”) wysuwa dwa rodzaje argumentów: po pierwsze - moralne. Nikt nie ma prawa „redukować” symbolu ludobójstwa do wydarzenia niemieckiego z lat 1940-1945 (auf ein deutsches Ereignis zwischen 1940 und 1945 zu reduzieren) $)^{47}$. Po drugie - praktyczne. Trudno sobie wyobrazić, żeby niemieccy, żydowscy, amerykańscy uczniowie zwracali się do siebie: jedziemy do Byłego Nazistowskiego Niemieckiego Obozu Koncentracyjnego Auschwitz-Birkenau. Pomijając dość absurdalny argument podnoszący niepraktyczność nowej nazwy, warto zwrócić uwagę na argument pierwszy. Odzwierciedla on wyraźną tendencję w niemieckiej narracji historycznej, którą można by nazwać „uniwersalizacją moralną” zbrodni. Przedstawiciele lewicy

46 Warto podkreślić, że inicjatywa zmiany nazwy obozu została podjęta na skutek coraz częstszych przypadków używania w prasie zagranicznej określenia „polskie obozy koncentracyjne”.

47 A. Widmann, Auschwitz lässt sich nicht umbenennen, „Berliner Zeitung”, 01.04.2006. 
i liberalnego centrum zaczęli używać terminologii i pojęć z zakresu podstawowych praw człowieka, kładąc szczególny nacisk na prawa jednostki. Hasła: „Hitler jest w każdym z nas”, „zbrodniarze nie mają narodowości”, „ofiary wobec cierpienia są równe”, używane często przez niemiecką lewicę najlepiej pokazują kierunek takiego rozumowania. Koncepcja taka została podchwycona przez Związek Wypędzonych i polityków z nim związanych, ale choć sama w sobie nie zasługuje na potępienie, pozbawiona kontekstu historycznego i nieuwzględniająca związków przyczynowo-skutkowych, staje się narzędziem manipulacji historią. Do takich zauważalnych w ostatnim czasie narzędzi należy między innymi odpowiednia hierarchizacja wydarzeń. O ile wiedza ogólna na temat Holocaustu w społeczeństwie niemieckim jest dość powszechna, a poczucie odpowiedzialności moralnej za ludobójstwo Żydów niepodważalne, o tyle nie istnieje w świadomości przeciętnego Niemca problem zbrodni na narodach słowiańskich. Jest to efektem odpowiedniej edukacji oraz dość wygodnego dla Niemców alibi - liczba ofiar żydowskich usprawiedliwia skupienie się jedynie na Holocauście ${ }^{48}$. Wśród ofiar obozów koncentracyjnych pojawiają się jeszcze Romowie oraz homoseksualiści, zawsze w tej samej kolejności ${ }^{49}$. Warto w tym miejscu podkreślić, iż wiedza Niemców na temat zbrodni II wojny światowej jest dość marna, o czym świadczy wiele badać przeprowadzonych przez różne niemieckie ośrodki naukowe. W 2012 roku Instytut Forsa przeprowadził badanie, którego wynik był dość szokujący. Przy znacznej trosce państwa niemieckiego o naukę dotyczącą Holocaustu, okazało się, że 21\% Niemców w wieku od 18

48 Trzeba podkreślić, że w narracji niemieckiej o Holocauście dominują przede wszystkim ogólne informacje, prasa niemiecka nie wdaje się w szczegóły, które uświadamiałyby, gdzie i w jaki sposób uśmiercano Żydów, szerzej patrz: A. Kwiatkowska-Drożdż, II wojna światowa w niemieckiej prasie - wybrane przykłady z rocznicowego roku 2005, Raport osw, czerwiec 2005; warto również przypomnieć, że samych polskich ofiar niemieckiej okupacji było co najmniej 2 mln (www.straty.pl).

49 A. Kwiatkowska-Drożdż, II wojna światowa..., s. 10. 
do 30 roku życia nie kojarzy z niczym słowa Auschwitz ${ }^{50}$. Inne badania ukazują, że nawet jeśli Niemcy znają ogólne liczby dotyczące Holocaustu, to zupełnie nie znają szczegółów „technicznych” ostatecznego rozwiązania ${ }^{51}$. Większość nie potrafi wyjaśnić, co działo się w obozach zagłady takich jak Dachau, Treblinka, a tym samym, nie znają roli państwa w zagładzie, nie rozumieją jej przemysłowego charakteru. W tym samym badaniu większość respondentów wykazała zupełny brak wiedzy o zbrodniach popełnionych w krajach okupowanych przez Niemców, m.in. w Grecji, Polsce, a nawet Związku Sowieckim, gdzie przecież przebiegał „mityczny” front wschodni ${ }^{52}$.

Argument podważający zasadność przypisywania odpowiedzialności za zbrodnie motywowane zbrodniczą ideologią (nazizm, komunizm) całemu narodowi podnosili nie tylko Niemcy. „Nie wszyscy Niemcy byli nazistami i nie wszyscy naziści byli Niemcami” - powiedziała angielska eurodeputowana baronowa Sara Ludford, która demonstracyjnie odmówiła podpisania rezolucji w sprawie uczczenia 6o. rocznicy wyzwolenia obozu Auschwitz, twierdząc, że obóz nie był wybudowany przez Niemców, lecz przez niemieckich nazistów ${ }^{53}$.

\section{Konkluzje}

Polityka historyczna państw prowadzona jest na różnych płaszczyznach, ale jedna z ważniejszych dotyczy narracji historycznej. Współcześnie prowadzona jest za pomocą wielu nowoczesnych narzędzi: badań naukowych (a szczególnie ich finansowania), filmu, internetu, prasy,

50 Jeder fünfte jüngere Deutsche kennt Auschwitz nicht, „Stern”, 25.01.2012.

51 Wywiad z z prof. B. Ortmeyerem w „Die Zeit” 27.02.2012, Nahezu ein schwarzes Loch, http://www.zeit.de/2012/o9/C-Interview-Lehrer-Ns-Zeit [28 vi 2015].

52 Tamże.

53 K. Zuchowicz, P. Zychowicz, Trzeba ścigać autorów tekstów o „polskich obozach śmierci”..., passim. 
książek. We wszystkich tych instrumentach zasadniczą rolę odgrywa słowo. Georg Orwell w „Roku 1984” napisał: Kto rządzi przeszłościa w tego rękach jest przyszłość; kto rzadzi teraźniejszościa, w tego rękach jest przeszłośćs ${ }^{54}$. Mimo, że Orwell pisał o stalinowskim systemie totalitarnym i manipulacji historią, do pewnego stopnia te słowa pozostają aktualne. Polityka historyczna jest przede wszystkim polityką, a więc głównym miernikiem jej efektywności jest skuteczność. Niemiecka polityka historyczna z pewnością należy do najlepszych na świecie: 70 lat po wojnie rozpętanej przez Rzeszę Niemiecką, którą w różnym stopniu popierało 90\% obywateli, RFN jest jednym z najbardziej pożądanych partnerów politycznych i gospodarczych na świecie. Co więcej w różnych rankingach sympatii, Niemcy zajmują zazwyczaj czołowe miejsca, nawet w Polsce sympatia do tego narodu z roku na rok rośnie ${ }^{55}$.

Zjednoczone Niemcy po mistrzowsku wykorzystują miękkie narzędzia w polityce zagranicznej (soft power) w tym przede wszystkim politykę historyczną. O ile we wcześniejszym okresie była ona skierowana na budowanie pozytywnego wizerunku RFN, o tyle w ostatnich latach skierowana jest również na zmianę wizerunku i roli Niemców w przeszłości. Ta tendencja powinna wywoływać zaniepokojenie i w razie potrzeby ostrą polską reakcję ${ }^{56}$.

Analizując działania różnych środowisk, agend rządowych, prasy niemieckiej, możemy zauważyć różne tendencje do zmieniania narracji dotyczącej II wojny światowej i zbrodni niemieckich, choć zdecydowanie zbyt daleko posunięte byłoby twierdzenie, że jest to wspólna, spójna, centralnie koordynowana polityka. Nie wyklucza to jednak jej wspólnego celu - destygmatyzacji narodu niemieckiego.

54 G. Orwell, Rok 1984, Warszawa 2007, s. 17.

55 Stosunek Polaków do innych narodów, Komunikat z badań своs, Warszawa luty 2014, s. 3 .

56 Polska polityka historyczna nie jest tematem niniejszego artykułu, więc wątek ten nie został tu rozwinięty. 


\section{Bibliografia}

Arendt H., Koncepcja historii: starożytna i nowożytna [w:] H. Arendt, Pomiędzy czasem minionym a przyszłym, Warszawa 2011, s. 78.

Arendt H., Pomiędzy czasem minionym a przyszłym, Warszawa 2011.

Bachmann K., Historia w krzywym zwierciadle, „Gazeta Wrocław”, 14.12.2008.

Buras P., Pamięć jako racja stanu. Niemiecka debata o stosunku do Holocaustu, „Więź”, nr 4: 1994, s. 142-147.

Die Walser-Bubis-Debatte. Eine Dokumentation, red. F.Schirrmacher, Frankfurt am Main 1999.

Frei N., Vergangenheitspolitik: Die Anfänge der Bundesrepublik und die Ns-Vergangenheit, München 1996.

Friedrich J., Die kalte Amnestie. Ns-Täter in der Bundesrepublik, Frankfurt a.M. 1985.

Giddens A., Nowoczesność i tożsamość, Warszawa 2001.

Giordano R., Die zweite Schuld oder Von Last Deutscher zu sein, Hamburg 1987.

Jaegger F., Rüsen J., Geschichte des Historismus. Eine Einführung, München 1992.

Jansen L., Alles Schlußstich - oder was? Eine philosophische Auseinandersetzungen mit Martin Walsers Friedenspreisrede, „Theologie und Philosophie" nr 80:2005, s. 412-422.

Jaspers K., Die Schuldfrage, Heidelberg 1946.

Jeder fünfte jüngere Deutsche kennt Auschwitz nicht, „Stern”, 25.01.2012.

Klinger K., MSZ nie radzi sobie z kłamstwami, „Dziennik Gazeta Prawna", 10.12.2009.

Koselleck R., Dzieje pojęć. Studia z semantyki i pragmatyki języka społeczno-politycznego, Warszawa 2009.

Koselleck R., Semantyka historyczna, wybór i oprac. H. Orłowski, Poznań 2001.

Kwiatkowska-Drożdż A., II wojna światowa w niemieckiej prasie - wybrane przykłady z rocznicowego roku 2005, http://www.osw.waw. 
$\mathrm{pl} / \mathrm{pl} /$ publikacje/raport-osw/2005-06-15/ii-wojna-swiatowa-wniemieckiej-prasie-wybrane-przyklady-z [15 I 2016].

Ławrynowicz J., Ławrynowicz M., „Polish Concentration Camps”. Zarys chronicznego problemu, „Przegląd Polski”, 28.01.2005.

Meinecke F., Die Deutsche Katastrophe. Betrachtungen und Erinnerungen, Wiesbaden 1946.

Nietzsche F, Niewczesne rozważania, tłum. L. Staff, Warszawa-Kraków 1912.

Notizbuch eines Philologen, Aufbau-Verlag, Berlin, 1947.

Nye J., Soft Power. Jak osiagnąć sukces w polityce światowej - perswazyjne środki oddziaływania politycznego (kultura, propaganda, dyplomacja), Warszawa 2007.

Orwell G., Rok 1984, Warszawa 2007.

Pieńkowski M., „Polskie obozy” wciąż w zachodnich mediach. Walka trwa, „Rzeczpospolita”, 27.01.2015.

Pietrzak L., Wielka kariera kłamstwa, „Uważam rze”, 07.04.2013.

Prof. Witold Kieżun dla wP.PL: większość moich studentów uważa Polaków za nazistów, wywiad z prof. Kieżunem dla Wirtualnej Polski, 15.07.2014, http://historia.wp.pl/title,Prof-Witold-Kiezun-dla-WPPL-wiekszosc-moich-studentow-uwaza-Polakow-za-nazistow, wid,16753214,wiadomosc.html?ticaid=1152c2 [15 I 2016].

Ranke von L., Geschichten der romanischen und germanischen Völker von 1494 bis 1535, Berlin-Lipsk 1824, tom 1, s. V-VI.

Ricoeur P., Pamięć, historia, zapominanie, Kraków 2012.

Ritter G., Europa und die deutsche Frage, Betrachtungen über die geschichtliche Eigenart des deutschen Staatsdenkens, München 1948

Rothbard M. N., Edukacja wolna i przymusowa, Warszawa 2014.

Rüsen J., Westliches Geschichtsdenken: Eine interkulturelle Debatte, Göttingen 1999.

Salmonowicz S., Prusy - dzieje państwa i społeczeństwa, Warszawa 1998.

Schenk D., Noc morderców. Kaźń polskich profesorów we Lwowie i holokaust w Galicji Wschodniej, Kraków 2011.

Stosunek Polaków do innych narodów, Komunikat z badań своs, Warszawa luty 2014. 
Weber A., Haben wir Deutsche nach 1945 versagt?, München 1949.

Widmann A., Auschwitz lässt sich nicht umbenennen, „Berliner Zeitung”, 01.04.2006.

Wolff-Powęska A., Geschichtspolitik. Geschichte im Dienst der Politik, TRANSODRA online, November 2006, http://www.transodra-online. net/de/node/1255 [29 Vi 2015].

Wspomnienie Tomasza Merty na portalu „Krytyki Politycznej” z dnia 15.04.2010, http://www.krytykapolityczna.pl/Opinie/GawinTomaszMerta-wspomnienie/menuid-183.html [27 VI 2015].

Wywiad z z prof. B. Ortmeyerem w „Die Zeit” 27.02.2012, Nahezu ein schwarzes Loch, http://www.zeit.de/2012/o9/C-Interview-Lehrer-NS-Zeit [28 vi 2015].

Zerbrechende Zeit. Über der Sinn der Geschichte, Böhlau, Köln 2001.

Zuchowicz K., Zychowicz P., Trzeba ścigać autorów tekstów o „polskich obozach śmierci”, „Rzeczpospolita”, 25.01.2005.

Zuchowicz K., Zychowicz P., Wygrywamy walkę o prawdę, „Rzeczpospolita", 22.04.2006. 